\title{
THE SYSTEMIC VISION OF ACCOUNTING
}

\author{
AssistantPh.D. Student Gomoi Bogdan Cosmin,bogdan_gomoi@yahoo.com \\ University „Aurel Vlaicu” of Arad
}

\begin{abstract}
If we imagine a long distance telephone company with no system in place to document who calls whom and how long they talk or a manager of a 300-unit apartment complex who has forgotten to write down which tenants have and have not paid the month's rent or an accounting professor who, the day before final grades are due, loses the only copy of the disk containing the spreadsheet of all the homework, quiz and exam scores, we realize that each of these scenarios illustrates a problem with bookkeeping, the least glamorous aspect of accounting. Bookkeeping is the preservation of a systematic, quantitative record of an activity and bookkeeping systems can be very primitive. But the importance of routine bookkeeping cannot be overstated; without bookkeeping, business is impossible.
\end{abstract}

In order to evaluate the importance of bookkeeping records, a thought experiment can be used. Supposing that, sometime, during the night, every copy of every novel ever written were to disappear, life wouldn't proceed normally the next day. While the cultural loss would be incalculable, the normal activities of the next day would be noticeably affected. If television were suddenly gone, the life would go on. But if the bookkeeping records of all businesses worldwide would be destroyed overnight, businesses that rely on up-to-the-minute customer account information, such as banks, simply could not open their doors. Retailers would have to insist on cash purchases, since no credit records could be verified. Manufacturers would have to do a quick count of existing inventories of raw materials and components to find out whether they could keep their production lines running. Suppliers would have to call all their customers, if they could remember who they were, to renegotiate purchase order. Attorneys would find themselves in endless arguments about their fees because they would have no record of billable hours. Routine and dry as bookkeeping may seem, the world simply could not function for one day without it.

Rudimentary bookkeeping is ancient, probably predating both language and money. The modern system of double-entry bookkeeping still in use today was developed in the 1300s - 1400s in Italy by the merchants in the trading and banking centers of Florence, Venice and Genoa. The key development in accounting in the last 500 years has been the use of the bookkeeping data, not just to keep track of things, but to evaluate the performance and health of a business. This use of bookkeeping data as an evaluation tool may seem obvious, but it is a step that is often not taken. We could consider bookkeeping system as a checking account. The checking account involves careful recording of the dates and amounts of all checks written and all deposits made, the maintenance of a running account total, and reconciliations with the monthly bank statement.

In summary, an accounting system is used by a business to analyze transactions, handle routine bookkeeping tasks and structure information so it can be used to evaluate the performance and health of the business. Accounting is formally defined as a system for providing ,quantitative information, primarily financial in nature, about economic entities that is intended to be useful in making economic decisions. There are several aspects regarding this definition. Thus, accounting relates to numbers. This is a strength because numbers can be easily tabulated and summarized. It is a weakness because some important business events, such as a toxic waste spill and the associated lawsuits and countersuits cannot be easily described by one or two numbers. In the same time, the health and performance of a business are affected by and reflected in many dimensions, such as financial, personal, relationships, community and environmental impact, and public image. 
Accounting focuses on just the financial dimension. In the same time, the practice of accounting is supported by a long tradition of theory. Although, accounting is the structured reporting of what has already occurred and this past information can only be useful if it impacts decisions about the future.

Making good decisions is critical for success in any business enterprise. When an important decision must be made, it is essential to use a rational decision-making process. The process is basically the same no matter how complex the issue is. First, the issue or question must be clearly identified. Next, the facts surrounding the situation must be gathered and analyzed. Then, several alternative courses of action should be identified and considered before a decision is finally reached. One must be careful to make a distinction between a good decision and a good outcome. Often, many factors outside the control of the decision maker affect the outcome of a decision. The decision-making process does not guarantee a certain result; it only ensures that a good decision is made. Accounting plays a vital role in the decision- making process. An accounting system provides information in a form that can be used to make knowledgeable financial decisions. The information supplied by accounting is in the form of quantitative data, primarily financial in nature, and relates to specific economic entities. An economic entity may be an individual, a business enterprise or a nonprofit organization. A business, such as a grocery store or a car dealership is operated with the objective of making a profit for its owners. The goal of a nonprofit organization, such as a city government or a university is to provide services in an effective and efficient manner. Every entity, regardless of its size or purpose must have a way to keep track of its economic activities and to measure how well it is accomplishing its goals. Accounting provides the means for tracking activities and measuring results.

Without accounting information, many important financial decisions would be made blindly. Investors, for example, would have no way to distinguish between a profitable company and one that is on the verge of failure. Bankers could not evaluate the riskiness of potential loans. Corporate managers would have no basis for controlling costs, setting prices or investing the company's resources. In the same time, governments would have no basis for taxing income. No list of examples could fully represent the pervasive use of accounting information throughout economic, social and political institutions. When accounting information is used effectively as a basis fr making economic decisions, limited resources are more likely to be allocated efficiently. From a board perspective, the result is a healthier economy and a higher standard of living.

Accounting is related to business. Business is the general term applied to the activities involved in the production and distribution of goods and services. Accounting is used to record and report the financial effects of business activities. Thus, accounting is often called ,the language of business". It provides the means of recording and communicating the successes and failures of business organizations. All business enterprises have some activities in common. One common activity is the acquisition of monetary resources. These resources, often referred to as „capital”, come from three sources: investors (owners), creditors (lenders) and the business itself in the form of earnings that have been retained. Once resources are obtained, they are used to buy land, buildings and equipment, to purchase materials and supplies, to pay employees and to meet any other operating expenses involved in the production and marketing of goods or services. When the product or service is sold, additional monetary resources (revenues) are generated. These resources can be used to pay loans, to pay taxes and to buy new materials, equipment and other items needed to continue the operation of the business. In addition, some of the resources may be distributed to owners as a return on their investment.

The accounting system generates output in the form of financial reports. There are two major categories of reports: internal and external. Internal reports are used by those who direct the day-to-day operations of a business enterprise. These individuals are collectively referred to as „management” and the related area of accounting is called management accounting. Management accounting focuses on the information needed for planning, implementing plans and controlling 
costs. Managers and executive who work inside a company have access to specialized management accounting information that is not available to outsiders. External financial reports, included in the firm's annual report are used by individuals and organizations that have an economic interest in the business but are not part of its management. Information is provided to these „external users" in the form of general-purpose financial statements and special reports required by government agencies. The general-purpose information provided by financial accounting is summarized in the three primary financial statements: balance sheet, income statement and statement of cash flows.

External users of the information contained in these three financial statements, along with other available information are the lenders, the investors, the management, the suppliers and customers, the employees, the competitors, the government agencies or even the press. Lenders (creditors) are interested în one thing and namely being repaid with interest. If you were to approach a bank or a large loan, the bank would ask you for several types of information in order to evaluate whether you would be able to repay the loan, such as: a listing of your assets and liabilities; payroll stubs, tax returns and other evidence of your income; details about any monthly payments (car, rent, credit cards) you are obligated to make or copies of recent bank statements to document the flow of cash into or out of your account. In essence, the bank would be asking you for a balance sheet, an income statement in making decisions about commercial loans. The financial statements are useful because they help the lender predict the future ability of the borrower to repay the loan. Investors want information to help them estimate how much cash they can expect to receive in the future if they invest in a business now. Financial statements, coupled with knowledge of business plans, market forecasts and the character of management can aid investors in assessing these future cash flows. Many companies have broad ownership with a few individuals owning a large portion of the company's stock. In addition to using management accounting information available only to those within the firm, managers of a company can use the general financial accounting information that is also made available to outsiders. Company goals are often stated in terms of financial accounting numbers, such as a target of sales growth in excess of 5\%. Also, reported "net income" is frequently used in calculating management bonuses. Finally, managers of a company can analyze the general-purpose financial statements in order to pinpoint areas of weakness about which more detailed management accounting information can be sought.

In some settings, suppliers and customers are interested in the long-run staying power of a company. Employees are interested in financial accounting information for a variety of reasons. As mentioned earlier, financial statement data are used in determining employee bonuses. In addition, financial accounting information can help an employee evaluate the likelihood that the employer will be able to fulfill its long-run promises, such as pensions and retiree health-care benefits. Financial statements are also important in contract negotiations between labor and management. Also, government agencies make frequent use of financial accounting information. Moreover, financial statements are a great place for a reporter to find background information to flesh out a story about a company.

In summary, who uses financial accounting information? Everyone does or, at least, everyone should. External financial reports come within the area of accounting referred to as financial accounting. Most of the data needed to prepare both internal and external reports is provided by the same accounting system. A major difference between management and financial accounting is the types of financial reports prepared. Internal reports are tailored to meet the needs of management and may vary considerably among businesses. General-purpose financial statements and other external reports, however, follow certain standards or guidelines and are thus more uniform among companies.

Another environmental factor affecting accounting and business, in general, is the growing concern over ethics. This concern was highlighted in a speech given by the chairman of the SEC, Arthur Levitt, in September 1998. In that speech, entitled "The Number's Game", Chairman Levitt identified several major accounting techniques that he believed were being used to undermine the 
integrity of financial reporting. Accounting involves significant judgment. Chairman Levitt expressed concern that this accounting judgment was giving way to pressure to "meet the numbers". In his speech, Chairman Levitt mentioned the standards of objectivity, integrity and judgment in reporting accounting numbers. These standards are an integral part of the public accounting profession's Code of Professional Conduct and form the foundation upon which audited financial statements are compiled and interpreted. The ethical dilemmas facing businesses and their accountants often revolve around pressure placed on companies by investors, creditors and potential investors and creditors. As Chairman Levitt mentioned, this pressures can sometimes cause company officials to become involved in "accounting hocus-pocus". Because accounting involves judgment, the reported accounting numbers can differ significantly depending on the assumptions made by those preparing the financial statements. To quote again from Chairman Levitt's speech, accounting principles "allow for flexibility to adapt to changing circumstances". It is this flexibility that creates many of the ethical dilemmas faced by accountants. As businesses come under pressure to report favorable performance, accountants may also come under pressure to "flex" the rules just a little too far. Fortunately, the public accounting profession is guided by a Code of Professional Conduct. Many other accounting organizations also have codes of conduct to provide guidance for their members.

\section{References}

1. Walter, T. Harrison jr., Charles, T. Horngren, Financial Accounting Second Edition, New Jersey, Prentice Hall Englewood Cliffs

2. Nobes, C.W., Parker, R., 2000, Comparative International Accounting, Editura Prentic Hall

3. Albrecht, S., Stice, J., Stice, E., Skousen, F., Accounting Concepts and Applications Edition 8, South-Western, Thomson Learning

4. Brigham, E., 1995, Fundamentals of Financial Management, Orlando, The Dryden Press

5. *** 2005, Consilier Management Financiar, Editura Rentrop \& Straton

6. *** 2005, Standardele Internationale de Raportare Financiara (IFRS), Editura CECCAR

7. *** OMFP 1752/2005 pentru aprobarea reglementarilor contabile conforme cu directivele europene 